\title{
EGG BROCHOSOMES OF PROCONIINI (HEMIPTERA: CICADELLIDAE, CICADELLINAE) SPECIES ASSOCIATED WITH CULTIVATION OF GRAPEVINES
}

\author{
Wilson Sampaio de Azevedo Filho ${ }^{1 *}$; Marcos Botton ${ }^{1}$; Andressa Paladini²; Gervásio Silva \\ Carvalho²; Rudiney Ringenberg $^{3}$; João Roberto Spotti Lopes ${ }^{3}$ \\ ${ }^{1}$ Embrapa Uva e Vinho, Lab. de Entomologia, R. Livramento, 515 - 95700-000 - Bento Gonçalves, RS - Brasil. \\ ${ }_{3}^{2}$ PUCRS - Depto. de Biodiversidade e Ecologia, Av. Ipiranga, 6681 - 90619-900 - Porto Alegre, RS - Brasil. \\ ${ }^{3}$ USP/ESALQ - Depto. de Entomologia, Fitopatologia e Zoologia Agrícola, C.P. 9 - 13418-900 - Piracicaba, SP - \\ Brasil. \\ *Corresponding author 〈azevedo@cnpuv.embrapa.br>
}

\begin{abstract}
Brochosomes production is considered a feature of Cicadellidae, and may represent an outstanding innovation which has played an important role in the development and diversification of this insect group. The objective of this study was to identify the species of Proconiini that produced egg brochosomes associated with grapevines in the Serra Gaúcha region of Brazil. Egg brochosome characteristics and an identification key are also discussed. The specimens were collected using yellow sticky cards in four vineyards (Vitis vinifera L.) from October 2004 to May 2006. Eight species capable of producing egg brochosomes were identified: Acrogonia citrina Marucci \& Cavichioli; Homalodisca ignorata Melichar;Molomea consolida Schröder;Molomea lineiceps Young;Molomea personata (Signoret); Oncometopia facialis (Signoret); Oncometopia fusca Melichar; and Tapajosa rubromarginata (Signoret). Egg brochosomes are useful structures to identify Proconiini species in vine.

Key words: Vitis vinifera, oviposition, leafhopper, taxonomy
\end{abstract}

\section{BROCOSSOMOS DE OVOS DE ESPÉCIES DE PROCONIINI (HEMIPTERA: CICADELLIDAE, CICADELLINAE) ASSOCIADAS À CULTURA DA VIDEIRA}

\begin{abstract}
RESUMO: A produção de brocossomos é considerada uma característica dos Cicadellidae e pode representar uma inovação importante no desenvolvimento e diversificação deste grupo. O objetivo do estudo foi identificar as espécies de Proconiini formadoras de brocossomos de ovos associadas à cultura da videira na região da Serra Gaúcha. As características dos brocossomos de ovos e uma chave para identificação também são discutidas. Os espécimes foram coletados com cartões adesivos amarelos em quatro vinhedos (Vitis vinifera L.) no período de outubro de 2004 a maio de 2006. Foram identificadas oito espécies com capacidade de produzir brocossomos de ovos: Acrogonia citrina Marucci \& Cavichioli; Homalodisca ignorata Melichar; Molomea consolida Schröder; Molomea lineiceps Young; Molomea personata (Signoret); Oncometopia facialis (Signoret); Oncometopia fusca Melichar e Tapajosa rubromarginata (Signoret). Os brocossomos de ovos são estruturas que podem ser utilizadas na identificação de espécies de Proconiini em videira.

Palavras-chave: Vitis vinifera, oviposição, cigarrinha, taxonomia
\end{abstract}

\section{INTRODUCTION}

Grape vine crops have suffered serious losses due to the occurrence of fungal and viral diseases, and insect pests. Currently, other countries are facing problems caused by the Pierce's disease caused by the bacterium Xylella fastidiosa, Cicadellidae and Cercopidae, popularly known as leafhoppers and spittlebugs, being the main vector groups (Varela et al., 2001). This plant pathogen, although not yet detected colonizing grape vine in Brazil, is common in plum, coffee, and citrus crops (Matiello \& Almeida, 1998; Hickel et al., 2001; Marucci et al., 2002), representing a constant threat to the development of the Brazilian winery and vineyard industry. The availability of new characters to identify leafhoppers associated with vineyards is an important tool within the context of an integrated management of these insects. 
Brochosomes are ultramicroscopic, reticulate, lipoprotein bodies produced by the Malpighian tubules and eliminated by the anus, present in several leafhopper species (Day \& Briggs, 1958; Vidano \& Arzone, 1984; Hix, 2001; Rakitov, 2002). These structures can be divided into two functional types: integument and egg brochosomes (Rakitov, 2002).

Egg brochosomes, either elongated or spherical (Figure 1A-D), can be found near the apical half

A

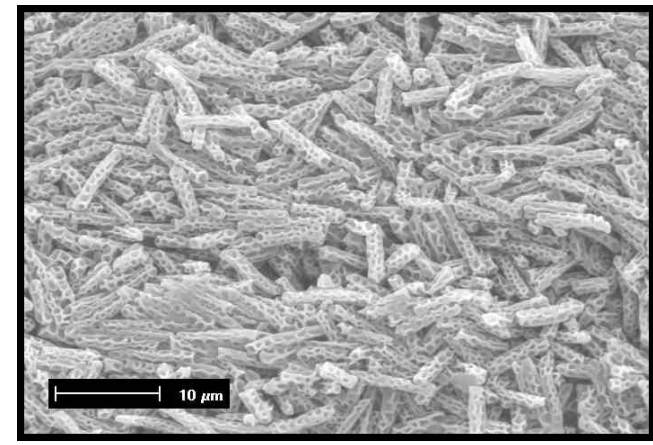

C

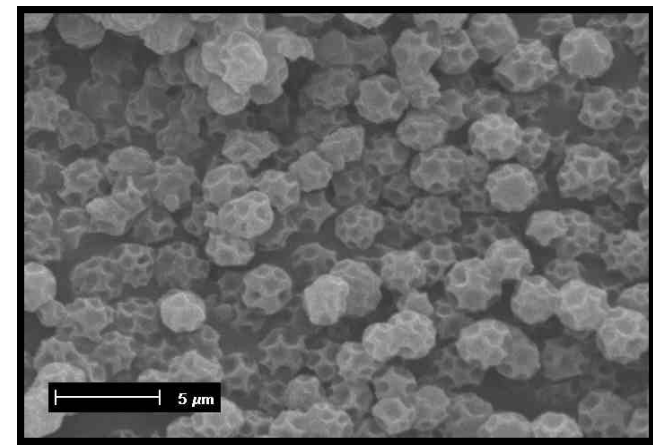

$\mathrm{E}$

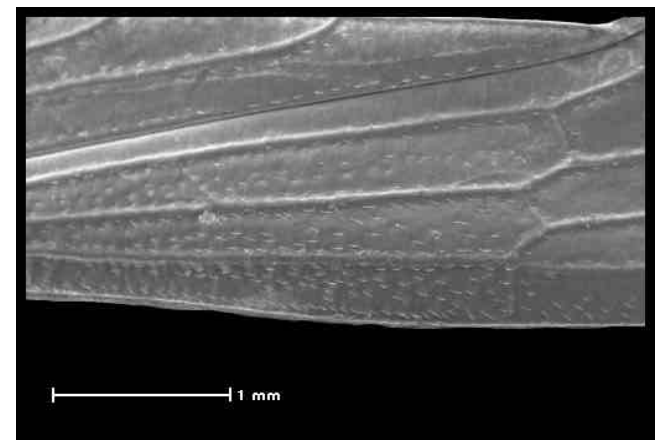

G

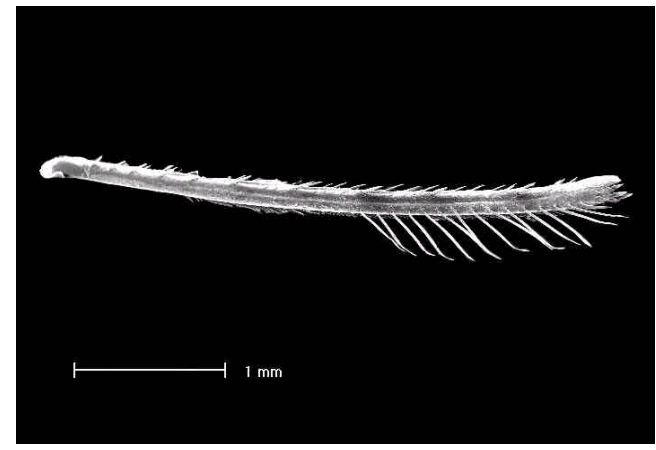

of the forewings in the form of convex masses, occurring in females (Figure 2A). Brochosome masses are attached to the wing surfaces by means of microbristles concentrated on the first discal cell, apex of the second, and part of the costal margin (Figure $1 \mathrm{E}-\mathrm{F})$. The macrobristles of the metathoracic tibiae (Figure 1G) are used to place the egg brochosomes on the wings and subsequently remove them, spreading them directly onto the egg mass or onto the scar

B

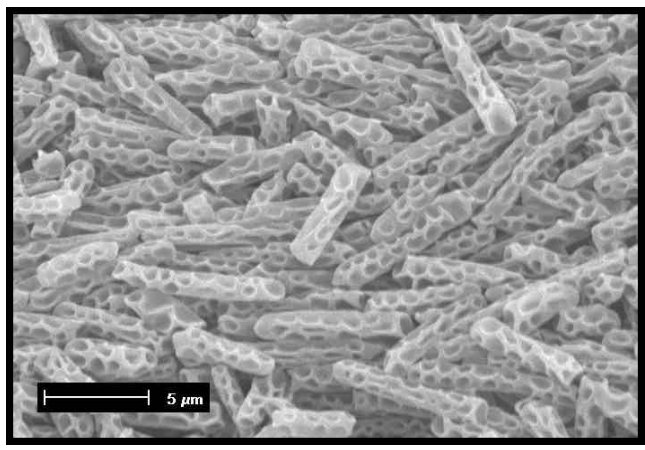

D

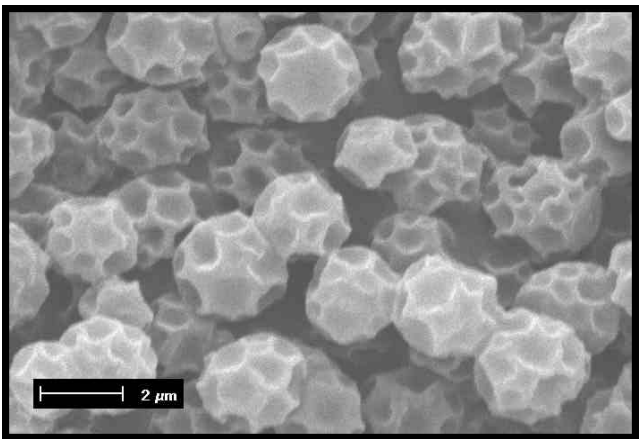

$\mathrm{F}$

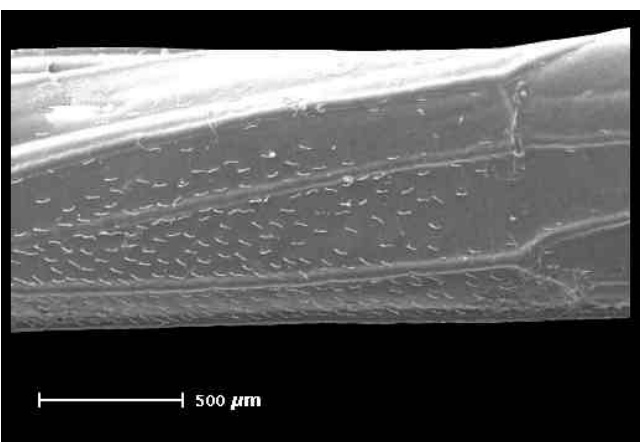

$\mathrm{H}$

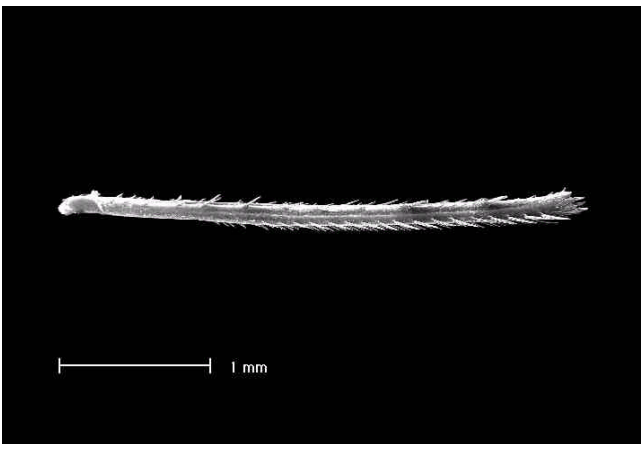

Figure 1 - A-D. Egg brochosomes. A-B. M. personata; C-D. T. rubromarginata. E-F. Forewings (dorsal view). E. M. lineiceps; F. A. citrina. G-H. A. citrina - metathoracic tibiae. G. Female; H. Male. 
made on the leaf during egg insertion (Rakitov, 1995, 1998, 1999; Hix, 2001). The females of species that produce this functional type of brochosome present longer macrobristles (metathoracic tibiae) than the corresponding males (Pollard \& Yonce, 1965) (Figure 1G-H). The functions of these structures are still little known, but some authors emphasize the possibility that they are associated with egg protection and to signal to other females that a given leaf has already been oviposited (Hix, 2001; Rakitov, 2002).

The objectives of this study were to identify egg brochosome-forming Proconiini species associated with grape vine crops (Vitis vinifera L.) prepare a dichotomous key for species by using these brochosomes; and characterize their structures relating them to their corresponding species.

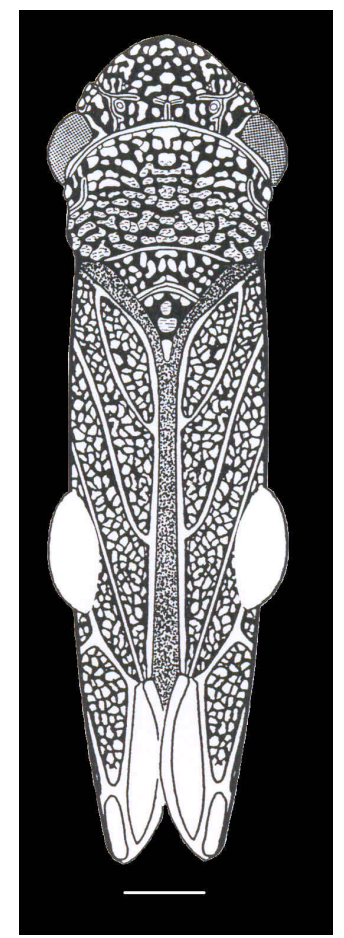

A

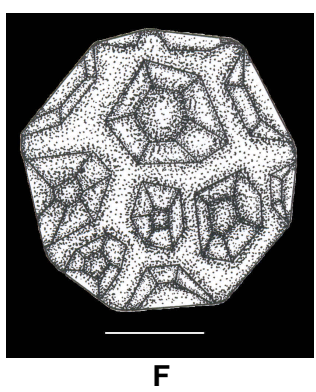

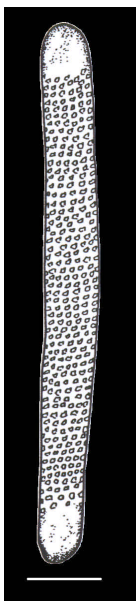

B

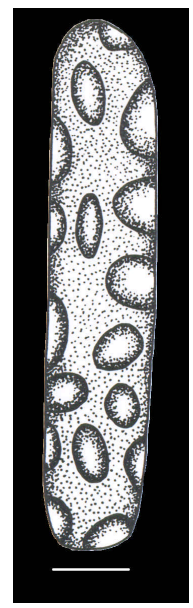

G

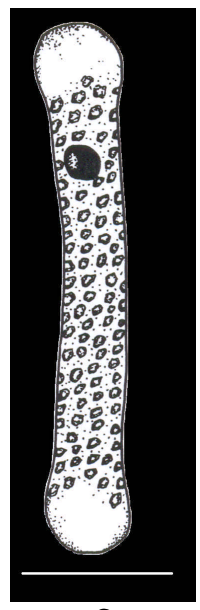

C

\section{MATERIAL AND METHODS}

Insect collections were made using yellow adhesive-coated cards (Biocontrole $-8.5 \times 11.5 \mathrm{~cm}$ ) in four commercial vineyards in the cities of Bento Gonçalves (three vineyards, $29^{\circ} 04^{\prime} \mathrm{S}$; $51^{\circ} 32^{\prime} \mathrm{W}$ of the cultivar Cabernet Sauvignon) and Farroupilha (one vineyard, $29^{\circ} 06^{\prime} \mathrm{S} ; 51^{\circ} 23 \mathrm{~W}$ - cultivar Moscato Embrapa) in the State of Rio Grande do Sul, Brazil. Twenty sticky cards were installed in each vineyard, distributed through ten points spaced at $40 \times 40 \mathrm{~m}$, with two cards per point, one $45 \mathrm{~cm}$ above ground and the other placed 45 $\mathrm{cm}$ above the leaf blade. Cards were replaced every 15 days during the period from October 2004 through May 2006. After capturing proconiines that showed egg brochosomes, individuals were re-

Figure 2 - A. T. rubromarginata (female) with masses of brochosomes attached to forewings (dorsal view). B-I. Egg brochosomes. B. A. citrina; C. H. ignorata; D. M. consolida; E. M. lineiceps; F. T. rubromarginata; G. M. personata; H. O. facialis; I. O. fusca. Scales: $\mathrm{A}=1 \mathrm{~mm}$; B-I $=1 \mu \mathrm{m}$. 
moved from the traps using solvent (kerosene - to dissolve the glue from the cards) and then mounted on pins.

The leafhoppers were identified based on Schröder (1959), Young (1968), and Azevedo-Filho \& Carvalho (2004). The egg brochosome study, together with its corresponding illustrations and measurements followed the methods described in Azevedo-Filho \& Carvalho (2005). The specimens are deposited with Coleção Entomológica da Embrapa Uva e Vinho (Entomological Collection), Bento Gonçalves/RS - Brazil (CEEUV).

\section{RESULTS AND DISCUSSION}

The egg brochosome-forming Proconiini species that occur on grape vine ( $V$. vinifera) in the Serra Gaúcha region are: Acrogonia citrina Marucci \& Cavichioli; Homalodisca ignorata Melichar; Molomea consolida Schröder; Molomea lineiceps Young; Molomea personata (Signoret); Oncometopia facialis (Signoret); Oncometopia fusca Melichar; and Tapajosa rubromarginata (Signoret). These species constitute new records on this crop.

Key for leafhopper species identification on grape vine based on egg brochosomes

1. Spherical brochosomes (Figure 2F) T. rubromarginata

1'. Elongate brochosomes....................................2

2. Filiform brochosomes..........................................3

2'. Fusiform brochosomes....................................6

3. Reticulate extremities........................................4

3'. Smooth extremities..........................................5

4. Structures with reticula not elaborated and depressed areas (Figure 2D)................. consolida

4'. Structures with conspicuous reticula, without depressed areas (Figure $2 \mathrm{G}$ ).................. personata

5. Structures with a conspicuous orifice (Figure 2C). H. ignorata

5'. Structures without such orifice (Figure 2B) A. citrina

6. Reticulation through the entire body length (Figure 2E). M. lineiceps

6'. Reticulation with a smooth apex.........................

7. Transition line between the reticulate and smooth areas slanted (Figure $2 \mathrm{H}$ ) o. facialis
7'. Transition line between the reticulate and smooth areas straight (Figure 2I)....................... fusca

The egg brochosomes for the species $M$. personata and T. rubromarginata are characterized ahead. With regard to the other Proconiini that were found, their structures are described in Azevedo-Filho \& Carvalho (2005). Because this egg brochosome analysis demonstrated that each species presents its structural type, these ultramicroscopic bodies represent another tool that can be used to identify Proconiini species on grape vine.

\section{Molomea personata (Signoret)}

Egg brochosomes - Length: $3.54 \mu \mathrm{m}$; width: $0.53 \mu \mathrm{m}$. Structures with a general filiform aspect, reticulation conspicuous through the entire body length (Figure 1A-B and 2G).

Comment - These are similar to the $M$. consolida egg brochosomes found in the present study, however, they can be easily distinguished for their conspicuous, significantly larger reticula, and for the lack of depressed areas; the species has egg brochosomes very similar to Pseudophera contraria (Walker), especially in relation to the reticulum shape and arrangement discussed by Rakitov (2004).

\section{Tapajosa rubromarginata (Signoret)}

Egg brochosomes - Diameter: $0.53 \mathrm{~mm}$. Structures with a general spherical aspect and reticulation through the entire body length (Figures 1C-D, $2 \mathrm{~A}$, and $2 \mathrm{~F}$ ).

Comment - Similar to integument brochosomes, also showing spherical and reticulate structures, found attached to the bodies of several leafhoppers, but with a more irregular reticulate configuration. Egg brochosomes generally display an elongate shape, but spherical shapes can be found in some species of the following genera: Homalodisca; Oncometopia, and Tapajosa (Rakitov, 2004). This species has egg brochosomes very similar to those of Tapajosa spinata Young, discussed by Rakitov (2004).

\section{ACKNOWLEDGEMENTS}

The authors thank CNPq and FAPERGS.

\section{REFERENCES}

AZEVEDO-FILHO, W.S.; CARVALHO, G.S. Guia para coleta e identificação de cigarrinhas em pomares de citros no Rio Grande do Sul. Porto Alegre: EDIPUCRS, 2004. 87p. 
AZEVEDO-FILHO, W.S.; CARVALHO, G.S. Brochosomes-for-Eggs of the Proconiini (Hemiptera: Cicadellidae, Cicadellinae) species associated with orchards of Citrus sinensis (L.) Osbeck in Rio Grande do Sul, Brazil. Neotropical Entomology, v.34, p.387394, 2005.

DAY, M.F.; BRIGGS, M. The origin and structure of brochosomes. Journal of Ultrastructure Research, v.2, p.239-244, 1958.

HICKEL, E.R.; JEAN-PIERRE, H.J.; DUCROQUET, H.J.; LEITEJUNIOR, R.P.; LEITE, R.M.V.B.C. Fauna de Homoptera: Auchenorrhyncha em pomares de ameixeira em Santa Catarina. Neotropical Entomology, v.30, p.725-729, 2001.

HIX, R.L. Egg-laying and brochosome production observed in glassywinged sharpshooter. California Agriculture, v.50, p.19-22, 2001.

MARUCCI, R.C.; CAVICHIOLI, R.R.; ZUCCHI, R.A. Espécies de cigarrinhas (Hemiptera: Cicadellidae: Cicadellinae) em pomares de citros da região de Bebedouro, SP, com descrição de uma nova espécie de Acrogonia Stål. Revista Brasileira de Entomologia, v.46, p.149-164, 2002.

MATIELLO, J.B.; ALMEIDA, S.R. 'Amarelinho' ou requeima das folhas do cafeeiro. Correio Agrícola, v.2, p.23-24, 1998.

POLLARD, H.N.; YONCE, C.E. Significance of length of tibial spines relative to oviposition processes by some leafhoppers (Hemiptera: Cicadellidae). Annals of the Entomological Society of America, v.58, p.594-595, 1965.

RAKITOV, R.A. The covering formed by brochosomes on the cuticle of leafhoppers (Homoptera, Cicadellidae). Entomological Review, v.74, p.90-103, 1995.

RAKITOV, R.A. On differentiation of cicadellid leg chaetotaxy. Russian Entomological Journal, v.6, p.7-27, 1998.
RAKITOV, R.A. Secretory products of the Malpighian tubules of Cicadellidae (Hemiptera, Membracoidea): an ultrastructural study. International Journal of Insect Morphology \& Embryology, v.28, p.179-193, 1999.

RAKITOV, R.A. What are brochosomes for? An enigma of leafhoppers (Hemiptera, Cicadellidae). Denisia, v.4, p.411432, 2002.

RAKITOV, R.A. Powdering of egg nests with brochosomes and related sexual dimorphism in leafhoppers (Hemiptera: Cicadellidae). Zoological Journal of the Linnean Society, v.140, p.353-381, 2004.

SCHRÖDER, H. Taxionomische und tiergeographische Studien an neotropischen Zikaden (Cicadellidae, Tettigellinae). Abhandlungen der Senckenbergischen Naturforschenden Gesellschaft, v.499, p.1-93, 1959.

VARELA, L.G.; SMITH, R.J.; PHILLIPS, P.A. Pierce's disease. Oakland: University of California, 2001. 20p.

VIDANO, C.; ARZONE, A. "Wax-area" in cicadellids and its connection with brochosomes from Malpighian tubules. Mitteilungen der Schweizerischen Entomologischen Gesellschaft, v.57, p.444-445, 1984.

YOUNG, D.A. Taxonomic study of the Cicadellinae. Part 1. Proconiini. U. S. National Museum Technical Bulletin, v.261, p.1-287, 1968.

Received September 12, 2006

Accepted October 22, 2007 